\title{
PEMANFAATAN PENGINDERAAN JAUH UNTUK IDENTIFIKASI PERMUKIMAN KUMUH DAERAH PENYANGGA PERKOTAAN (Studi Kasus : Kecamatan Mranggen Kabupaten Demak)
}

\author{
R.A.Ramadhan ${ }^{\text {a }}$, B.Pigawati ${ }^{\text {b }}$ \\ ${ }^{a}$ Universitas Diponegoro, Indonesia, email: rezkyarieframadhan@gmail.com \\ ${ }^{b}$ Universitas Diponegoro, Indonesia, email: bitta.pigawati@gmail.com
}

Article Info;

Received:

23 September 2014

in revised form:

25 September 2014

Accepted:

27 September 2014

Available Online:

1 October 2014

Keywords:

Characteristics, Slums, Buffer Area,

Mranggen

Subdistrict

Info Artikel;

Diterima:

23 September 2014

Hasil Revisi :

25 September 2014

Disetujui:

24 September 2014

Publikasi On-Line:

1 Oktober 2014

Kata kunci:

Karakteristik,

Permukiman Kumuh, Daerah Penyangga, Kecamatan Mranggen

\begin{abstract}
Mranggen Subdistrict is one of the buffer zone area for Semarang City that slums area can be found. Emergence of slums area in Mranggen Subdistrictis because the impact of increased population in Semarang Capital. Increasing of the settlements area and housing become a logical consequence that comes from the main case. This condition is a major trigger from the formation of slums area. The purpose of this research is to identify characteristics of slums area in Mranggen Subdistrict, as a buffer area for Semarang Capital, with a quantitative approaching method. Instruments used in this research were observation, interview, and kuesioner with descriptive and spatial analytical techniques. Interpretation of Alos satellite's citra is about to know the distribution of slums area. The results showed that some of the slums area in Mranggen Subdistrict has a bad quality of buildings, semi-permanent and nonpermanent buildings still stands, varying distance between the buildings was like $(<1,5$ meters, 1,5-3,0 meters, and > 3,0 meters). Location of the slums area is very strategic that so many people could make an easy access towards the working place. Condition of the road was good, but condition of the drainage system, clean water, and sanitation were bad. Many house that have not been certified yet, low level of population growth and density, low rate income, also migrants people that prefers to live in this location rather than the other places, because near from their working place. So, strategic ways to handle slums area in Mranggen Subdistrict can be done using poverty development, community based development, and guided land development approach.
\end{abstract}

\begin{abstract}
Abstrak: Kecamatan Mranggen merupakan salah satu daerah penyangga Kota Semarang yang teridentifikasi memiliki kawasan permukiman kumuh. Munculnya kawasan permukiman kumuh di Kecamatan Mranggen merupakan dampak dari meningkatnya jumlah penduduk Kota Semarang. Pertambahan luas permukiman dan pemadatan rumah mukim menjadi konsekuensi logis yang selalu menyertai gejala ini. Hal ini menjadi pemicu terbentuknya permukiman kumuh. Penelitian ini bertujuan untuk mengkaji karakteristik kawasan permukiman kumuh di Kecamatan Mranggen sebagai daerah penyangga Kota Semarang dengan menggunakan pendekatan kuantitatif. Instrumen penelitian yang digunakan adalah observasi, wawancara, dan kuesioner dengan teknik analisis deskriptif dan spasial. Teknik analisis spasial digunakan untuk mengetahui persebaran kawasan permukiman kumuh di Kecamatan Mranggen melalui interpretasi citra satelit Alos. Hasil penelitian menunjukkan bahwa karakteristik permukiman kumuh di Kecamatan Mranggen kualitas bangunannya rendah, banyak terdapat bangunan semi permanen dan non permanen, jarak antar bangunan bervariasi (<1,5 meter, 1,5-3,0 meter, dan > 3,0 meter). Lokasi kawasan permukiman kumuh sangat strategis sehingga memungkinkan penduduk dapat mengakses tempat kerja dengan mudah. Kondisi prasarana jalan baik namun kondisi drainase, air bersih, dan sanitasi buruk. Masih banyak rumah yang belum bersertifikat, tingkat pertumbuhan dan kepadatan penduduk rendah, tingkat pendapatan rendah, dan alasan penduduk pendatang yang memilih tinggal di kawasan permukiman kumuh karena dekat dengan tempat kerja. Untuk penangan kawasan permukiman kumuh di Kecamatan Maranggen dapat dilakukan melalui pendekatan poverty development, community based development, dan guided land development.
\end{abstract}




\section{PENDAHULUAN}

Identifikasi karakteristik kawasan permukiman kumuh di daerah penyangga perkotaan menjadi cukup strategis manakala kawasan tersebut memiliki kaitan atau berbatasan langsung dengan pusat kota. Penelitian ini bermaksud untuk melengkapi kajian tentang permukiman kumuh di kawasan pesisir Kota Semarang yang telah di lakukan sebelumnya oleh Bitta Pigawati (2014). Kecamatan Mranggen merupakan salah satu daerah penyangga Kota Semarang yang teridentifikasi memiliki kawasan permukiman kumuh. Munculnya kawasan permukiman kumuh di Kecamatan Mranggen merupakan dampak dari meningkatnya jumlah penduduk Kota Semarang. Wilayah Kecamatan Mranggen, khususnya Desa Kangkung, Desa Batursari, dan Desa Mranggen yang letaknya dekat dengan Kota Semarang merupakan sasaran bagi pendatang-pendatang baru untuk bertempat tinggal, baik pendatang dari bagian dalam kota maupun pendatang dari bagian yang lebih jauh dari itu. Bagi pendatang yang berasal dari bagian dalam kota, Kecamatan Mranggen merupakan daerah yang sangat menarik untuk bertempat tinggal, karena menawarkan tingkat kenyamanan yang jauh lebih tinggi ketimbang suasana yang ada di bagian dalam kota. Sementara bagi pendatang yang berasal dari luar kota, Kecamatan Mranggen merupakan daerah yang tepat untuk memperoleh peluang kerja yang lebih besar. Pertambahan luas lahan permukiman dan pemadatan rumah mukim menjadi konsekuensi logis yang selalu menyertai gejala ini. Hal ini merupakan pemicu utama terjadinya taudifikasi atau proses terbentuknya permukiman kumuh. Peta citra Kecamatan Mranggen dapat dilihat pada Gambar 1.

Gambar 1.Peta Citra Kecamatan Mranggen (Citra Alos, 2011)

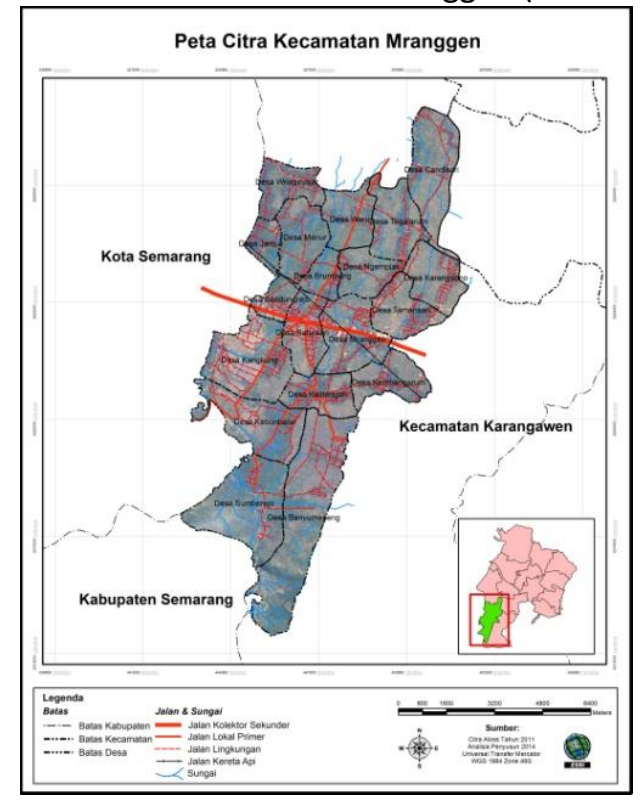

Berdasarkan kondisi tersebut, penelitian ini bertujuan untuk mengidentifikasi karakteristik kawasan permukiman kumuh di Kecamatan Mranggen sebagai daerah penyangga Kota Semarang. Untuk penanganan kawasan permukiman kumuh dapat dilakukan diantaranya melalui pendekatan poverty development, community based development (CBD), dan guided land development (GLD). Poverty development adalah pendekatan yang berangkat dari pemahaman bahwa kawasan permukiman kumuh akan dikelola secara komersial agar ekonomi lokasi yang tinggi dimanfaatkan semaksimal mungkin bagi kepentingan kawasan. Community based development (CBD) dan guide land development (GLD) adalah pendekatan berdasarkan pemahaman bahwa kawasan kurang bahkan hampir tidak mempunyai nilai ekonomis komersial. Perbedaannya, CBD menempatkan masyarakat sebagai pemeran utama. Sementara, GLD lebih mengarah dan melindungi hak penduduk asal untuk tetap tinggal (Dirjen Cipta Karya, 2006).

Perkembangan kondisi fisik dan penduduk memunculkan masalah permukiman yang terkait dengan kualitas lingkungan. Kondisi ini terus berkembang sehingga di dalam penyelenggaraan pembangunan permukiman perlu pendekatan yang terpadu dan dukungan kebijakan yang meliputi berbagai aspek (Pigawati. B, 2014). 


\section{DATA DAN METODE}

\subsection{Penginderaan Jauh}

Penginderaan jauh berasal dari dua kata dasar yaitu indera berarti melihat, dan jauh berarti jarak jauh. Jadi berdasarkan asal katanya (epistimologi), penginderaan jauh berarti melihat objek dari jarak jauh. Lillesand dan Kiefer (1999) dalam Mulyadi (2007) mendefinisikan penginderaan jauh sebagai ilmu dan seni untuk memperoleh informasi tentang objek, daerah atau gejala dengan jalan menganalisis menggunakan kaidah ilmiah, dan data yang diperoleh dengan menggunakan alat tanpa kontak langsung terhadap objek, daerah, atau gelaja yang dikaji.

\subsection{Permukiman Kumuh}

Permukiman kumuh adalah suatu kawasan dengan bentuk hunian yang tidak berstruktur, tidak berpola (misalnya letak rumah dan jalannnya tidak beraturan, tidak tersedianya fasilitas umum, prasarana dan sarana air bersih, MCK), dan bentuk fisiknya tidak layak misalnya secara regular tiap tahun kebanjiran (Yudohusodo, 1991). Sementara menurut Khomarudin (1997), kawasan permukiman kumuh dapat didefinisikan sebagai :

a. Lingkungan yg berpenghuni padat (melebihi 500 org per $\mathrm{Ha}$ );

b. Kondisi sosial ekonomi masyarakat yang rendah;

c. Jumlah rumah yang sangat padat dan ukurannya dibawah standar;

d. Sarana prasarana tidak ada atau tidak memenuhi syarat teknis dan kesehatan;

e. Hunian yang dibangun diatas tanah milik negara atau orang lain dan diluar perundang-undangan yang berlaku.

Menurut UN-HABITAT (2003) faktor-faktor yang menyebabkan kawasan menjadi kumuh diantaranya adanya migrasi penduduk dari desa ke kota, urbanisasi, dan kombinasi urbanisasi dan migrasi sebagai akibat dari perpindahan konflik antar penduduk. Giok Ling (2007) memiliki pendapat yang berbeda, menurutnya permukiman kumuh dapat pula terbentuk tanpa adanya tingkat urbanisasi yang sangat cepat. Tetapi lebih disebabkan karena pemerintah tidak memiliki kapasita. dalam mengatasi urbanisasi yang cepat.

Hasil penelitian Bitta Pigawati (2014), menunjukkan ada keterkaitan antara jumlah penduduk miskin dengan kondisi kumuhnya suatu kawasan permukiman, sehingga salah satu pendekatan penanganan permukiman kumuh dapat ditempuh melalui srtategi penanggulangan kemiskinan.

Ciri-ciri kawasan permukiman kumuh menurut Hari Srinivas (2003) dapat tercermin dari :

1. Penampilan fisik bangunannya yang miskin konstruksi, yaitu banyaknya bangunan-bangunan temporer yang berdiri serta nampak tak terurus maupun tanpa perawatan;

2. Pendapatan yang rendah mencerminkan status ekonomi mereka, biasanya masyarakat kawasan kumuh berpenghasilan rendah;

3. Kepadatan bangunan yang tinggi, dapat terlihat dari tidak adanya jarak antar bangunan maupun siteplan yang tidak terencana;

4. Kepadatan penduduk yang tinggi dan masyarakatnya yang heterogen;

5. Sistem sanitasi yang miskin atau tidak dalam kondisi yang baik;

6. Kondisi sosial yang tidak baik dapat dilihat dengan banyaknya tindakan kejahatan maupun kriminal;

7. Banyaknya jumlah masyarakat pendatang yang bertempat tinggal dengan menyewa rumah.

\subsection{Daerah Penyangga}

Daerah penyangga merupakan daerah yang tumbuh akibat proses pertumbuhan wilayah-wilayah tertentu dengan aktivitasnya yang bersifat agraris dan non agraris yang ditandai dengan interaksi antara manusia dan komoditasnya (Bintarto, 1983). Menurut Tarigan (2005), daerah penyangga diartikan sebagai daerah yang langsung berbatasan dengan wilayah kota / areal terbangun (built up area). Daerah penyangga tersebut saat ini tidak termasuk dalam wilayah terbangun secara penuh (full developed), namun dalam waktu mendatang akan mengalami perubahan karena perkembangan kota, atau dengan kata lain batasan tersebut dapat mencakup suatu pengertian bahwa daerah penyangga adalah wilayah dalam lingkungan administratif yang bersentuhan dengan wilayah administratif lain. Yunus (2008) mengemukakan definisi yang berbeda yakni daerah penyangga merupakan wilayah yang 
berada di antara wilayah kekotaan dan wilayah kedesaan. Ciri khas wilayah ini sangat istimewa yang tidak dimiliki oleh wilayah lain yaitu dalam hal keterkaitan yang begitu besar dengan aspek kehidupan kota maupun desa yang tercipta secara simultan. Menurut Bintarto (1983), beberapa alasan tumbuhnya daerah penyangga antara lain;

1. Peningkatan pelayanan transportasi kota;

2. Pertumbuhan penduduk yang tinggi;

3. Meningkatnya taraf hidup masyarakat;

4. Gerakan pemilikan rumah oleh masyarakat;

Menurut Malaque (2007) tumbuhnya daerah penyangga juga dapat dilihat dari adanya perubahan penggunaan lahan. Malaque (2007) menambahkan bahwa perubahan penggunaan lahan di daerah penyangga atau kawasan pinggiran dapat ditandai dengan berubahnya status kepemilikan lahan dan munculnya permintaan akan tempat tinggal. Yunus (2008) sependapat dan menambahkan bahwa daerah penyangga perkotaan merupakan sasaran perkembangan fisikal baru dari suatu kota. Transformasi spasial yang terjadi di daerah penyangga merupakan proses berubahnya penggunaan lahan yang berorientasi pada kepentingan kedesaan menjadi penggunaan lahan yang berorientasi pada kepentingan kekotaan.

Penelitian yang berjudul karakteristik kawasan permukiman kumuh daerah penyangga perkotaan Semarang (studi kasus : Kecamatan Mranggen Kabupaten Demak) menggunakan pendekatan kuantitatif. Instrumen penelitian yang digunakan adalah observasi, wawancara, dan kuesioner. Untuk mengetahui jumlah sampel, teknik sampling yang digunakan adalah simple random sampling dan stratified sampling dengan jumlah sampel 269 (tingkat kesalahan 10\%).

Teknik analisis yang digunakan adalah teknik analisis deskriptif dan spasial. Analisis dalam penelitian ini diantaranya adalah analisis penggunaan lahan di Kecamatan Mranggen yang dilakukan untuk mengetahui persebaran kawasan permukiman kumuh melalui interpretasi citra satelit Alos tahun 2011. Analisis permukiman kumuh dilakukan untuk mengetahui karakteristik kawasan permukiman kumuh berdasarkan kondisi bangunan, aksesbilitas, prasarana, status tanah, kondisi kependudukan, dan kondisi sosial ekonomi serta tingkat kekumuhannya secara deskriptif dan spasial. Analisis karakteristik permukiman kumuh dilakukan untuk mengetahui karakteristik permukiman kumuh Kecamatan Mranggen sebagai daerah penyangga Kota Semarang secara deskriptif dan spasial. Kerangka analisis dapat dilihat pada gambar 2.

\section{HASIL DAN PEMBAHASAN}

\subsection{Analisis Penggunaan Lahan Kecamatan Mranggen}

Kawasan permukiman kumuh di Kecamatan Mranggen memiliki luas 1652,94 Ha atau 54\% dari luas total permukiman. Persebaran kawasan permukiman kumuh di Kecamatan Mranggen dapat dilihat pada tabel 1.

Tabel 1. Persebaran Kawasan Permukiman Kumuh Kecamatan Mranggen (Hasil Analisis, 2014)

\begin{tabular}{|c|c|c|}
\hline \multirow[t]{2}{*}{ Desa } & \multicolumn{2}{|c|}{ Kawasan Permukiman Kumuh } \\
\hline & $\begin{array}{l}\text { Luas } \\
\text { (Ha) }\end{array}$ & $\begin{array}{c}\text { Prosentase } \\
\text { (\%) }\end{array}$ \\
\hline Banyumeneng & 116,93 & 7,07 \\
\hline Sumberejo & 49,97 & 3,02 \\
\hline Kebonbantur & 166.15 & 10,05 \\
\hline Batursari & 182,56 & 11,04 \\
\hline Kangkung & 109,15 & 6,60 \\
\hline Kalitengah & 148,13 & 8,96 \\
\hline Kembangarum & 94,15 & 5,70 \\
\hline Mranggen & 149,88 & 9,07 \\
\hline Bandungrejo & 36,42 & 2,20 \\
\hline Brumbung & 45,90 & 2,78 \\
\hline
\end{tabular}




\begin{tabular}{lcc}
\hline \multicolumn{1}{c}{ Desa } & \multicolumn{2}{c}{ Kawasan Permukiman Kumuh } \\
\cline { 2 - 3 } & $\begin{array}{c}\text { Luas } \\
\text { (Ha) }\end{array}$ & $\begin{array}{c}\text { Prosentase } \\
\text { (\%) }\end{array}$ \\
\hline Ngemplak & 89,07 & 5,39 \\
\hline Karangsono & 67,31 & 4,07 \\
\hline Tamansari & 87,09 & 5,27 \\
\hline Menur & 61,82 & 3,74 \\
\hline Jamus & 28,01 & 1,69 \\
\hline Wringinjajar & 69,81 & 4,22 \\
\hline Waru & 32,28 & 1,95 \\
\hline Tegalarum & 75,33 & 4,56 \\
Candisari & 42,99 & 2,60 \\
\hline
\end{tabular}

Berdasarkan tabel 1 dapat diketahui, Desa Batursari merupakan desa dengan kawasan permukiman kumuh terluas yakni $182,56 \mathrm{Ha}(11,04 \%)$ dari luas total permukiman karena lokasinya yang strategis yakni berada di pusat kota kecamatan dan dilalui jalan Semarang-Purwodadi sehingga penduduk lebih memilih tinggal di wilayah ini. Sementara, Desa Jamus merupakan desa dengan kawasan permukiman kumuh terkecil yakni $28,01 \mathrm{Ha}(1,69 \%)$ dari luas total permukiman karena lokasinya yang kurang strategis. Untuk lebih jelasnya, peta citra dan persebaran kawasan permukiman kumuh di Kecamatan Mranggen secara spasial dapat dilihat pada gambar 3.

Gambar 2. Kerangka Analisis (Hasil Analisis, 2014)

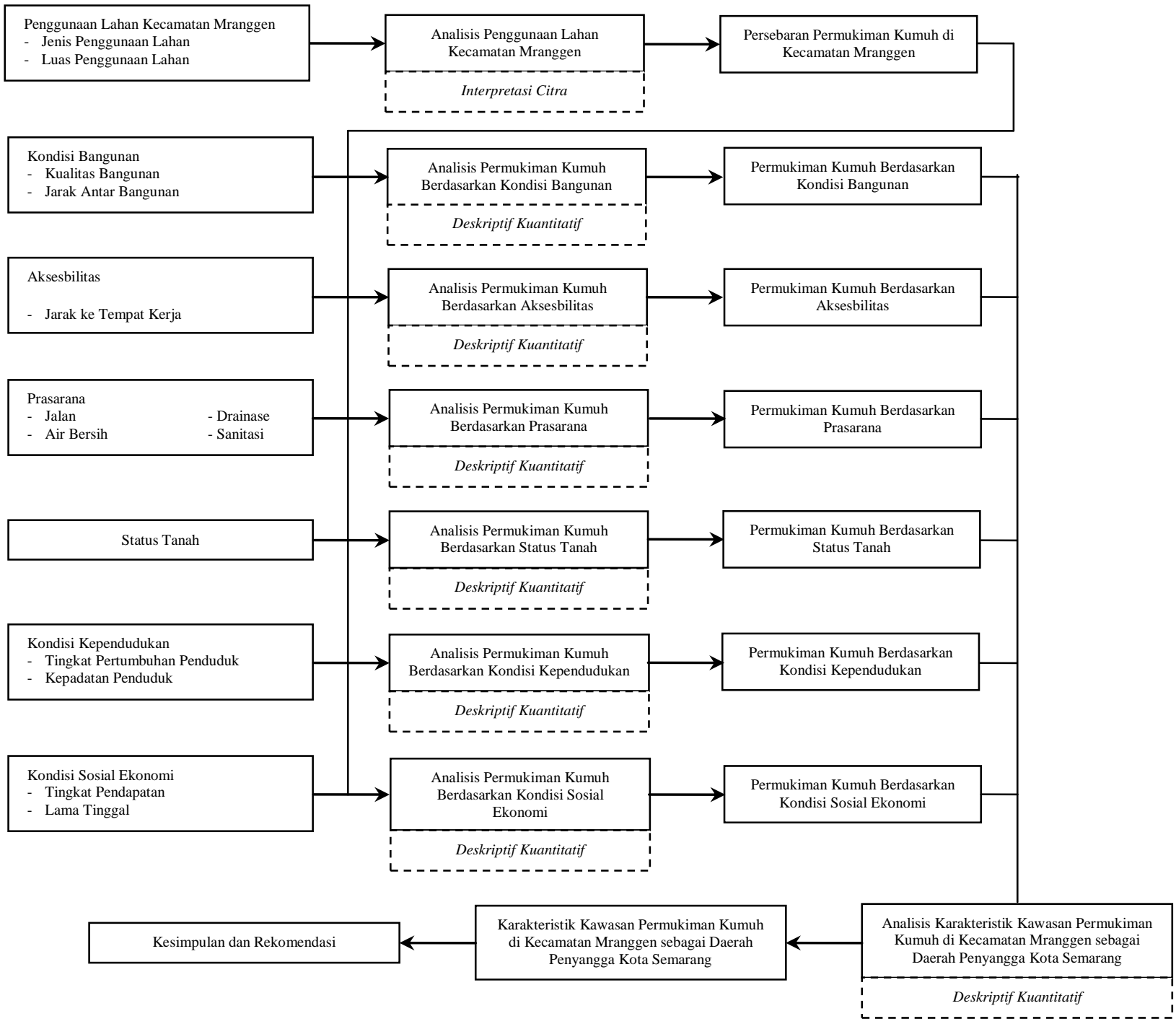


Gambar 3. Peta Citra Kecamatan Mranggen (Kiri), dan Peta Persebaran Kawasan Permukiman Kumuh Kecamatan Mranggen (Kanan)(Citra Alos dan Interpretasi Alos, 2011)
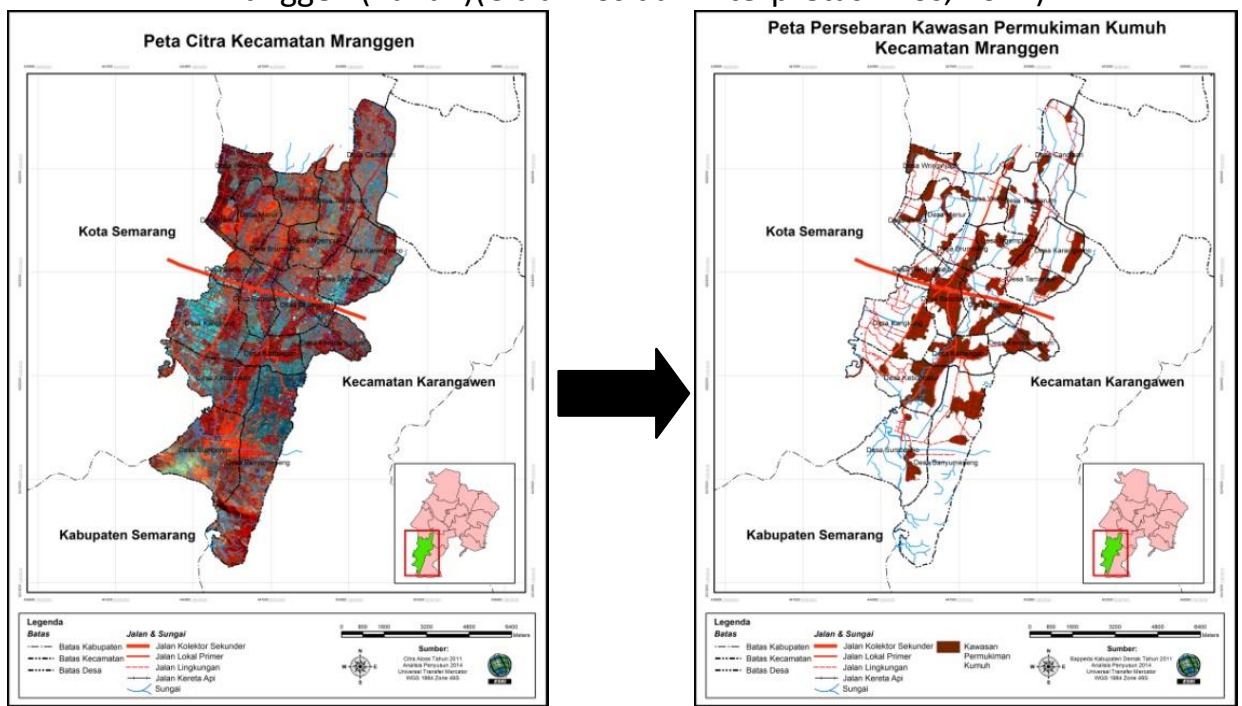

\subsection{Analisis Permukiman Kumuh Berdasarkan Kondisi Bangunan}

Jenis bangunan kawasan permukiman kumuh di Kecamatan Mranggen merupakan bangunan semi permanen dan non permanen. Sebanyak $43 \%$ jenis bangunan rumah penduduk merupakan bangunan semi permanen, dan sebanyak $57 \%$ jenis bangunan rumah penduduk merupakan bangunan non permanen. Jarak antar bangunan rumah bervariasi yakni $<1,5$ meter, 1,5 $-3,0$ meter, dan $>3,0$ meter. Untuk jarak antar bangunan $<1,5$ meter, antara bangunan satu dengan yang lain hanya dipisahkan oleh tanah, sementara untuk jarak antar bangunan 1,5-3,0 meter dan >3,0 meter, antara bangunan satu dengan yang lain dipisahkan oleh tanah atau pekarangan. Kondisi ini dipengaruhi oleh kemampuan finansial penduduk dalam membangun tempat tinggal. Penduduk yang tinggal di rumah dengan bangunan semi permanen dapat dikatakan memiliki kemampuan finansial lebih baik daripada tinggal di rumah dengan bangunan non permanen. Jenis bangunan dan jarak antara bangunan permukiman di Kecamatan Mranggen dapat dilihat pada gambar 4;

Gambar 4. Jenis Bangunan Non-Permanen (Kiri), dan Jarak Antar Bangunan $<1,5$ meter (Kanan),

(Hasil Survei Primer, 2014)
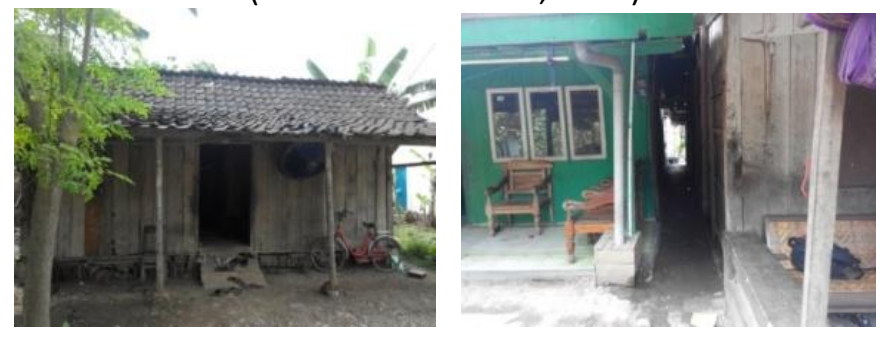

\subsection{Analisis Permukiman Kumuh Berdasarkan Aksesbilitas}

Tingkat aksesbilitas kawasan permukiman kumuh di Kecamatan Mranggen tinggi. Sebanyak $42 \%$ penduduk menyatakan jarak dari rumahnya menuju tempat kerja $<1 \mathrm{~km}$, sebanyak $26 \%$ penduduk menyatakan jarak dari rumahnya menuju tempat kerja antara $1-5 \mathrm{~km}$, sebanyak $19 \%$ penduduk menyatakan jarak dari rumahnya menuju tempat kerja antara $6-10 \mathrm{~km}$, dan sisanya sebanyak $13 \%$ penduduk menyatakan jarak dari rumahnya menuju tempat kerja $>10 \mathrm{~km}$. Desa Bandungrejo, Desa Batursari, dan Desa Mranggen memiliki lokasi yang strategis karena dilalui jalan Semarang-Purwodadi, dekat dengan pusat perdagangan (pasar dan pertokoan) dan pusat pemerintahan (kantor kecamatan). Desa Bandungrejo, Desa Kangkung, Desa Jamus, Desa Wringinjajar, dan Desa Kebonbatur juga memiliki lokasi yang strategis karena dekat dengan Kota Semarang. Desa Tegalarum, Desa Waru, Desa 
Brumbung, Desa Menur, Desa Ngemplak, Desa Kalitengah, Desa Tamansari, Desa Kembangarum, dan Desa Karangsono memiliki lokasi yang cukup strategis karena berada pada "lapis kedua" dari wilayah desa yang dekat dengan Kota Semarang dan jalur yang menghubungkan Kota Semarang dengan Kabupaten Purwodadi. Fungsi lain yang berada di kawasan ini berupa fungsi campuran yakni permukiman dan perdagangan dan jasa. Desa Candisari, Desa Banyumeneng, dan Desa Sumberejo memiliki lokasi yang kurang strategis karena berada pada "lapis ketiga" dari wilayah desa yang dekat dengan Kota Semarang dan jalur yang menghubungkan Kota Semarang dengan Kabupaten Purwodadi. Wilayah ini berada di ujung utara dan selatan Kecamatan Mranggen. Fungsi lain yang berada di kawasan ini berupa fungsi permukiman dan persawahan.

\subsection{Analisis Permukiman Kumuh Berdasarkan Prasarana}

Kondisi jalan kawasan permukiman kumuh di Kecamatan Mranggen baik sehingga yang dapat mendukung tingkat mobilitas penduduk tinggi. Namun kondisi drainase, air bersih, dan sanitasi buruk. Kondisi drainase terkesan kurang terpelihara karena sebagian besar saluran drainase kering dan dipenuhi dengan sampah. Kondisi air bersih keruh karena kurangnya kontrol pemerintah terhadap kualitas air bersih. Sebagian besar kawasan permukiman kumuh tidak memiliki jamban atau memiliki tapi dalam kondisi buruk. Penduduk yang tidak memiliki jamban biasanya memanfaatkan sungai atau saluran untuk buang air besar. Foto kondisi jalan, drainase, air bersih, dan sanitasi dapat dilihat pada gambar 5 .

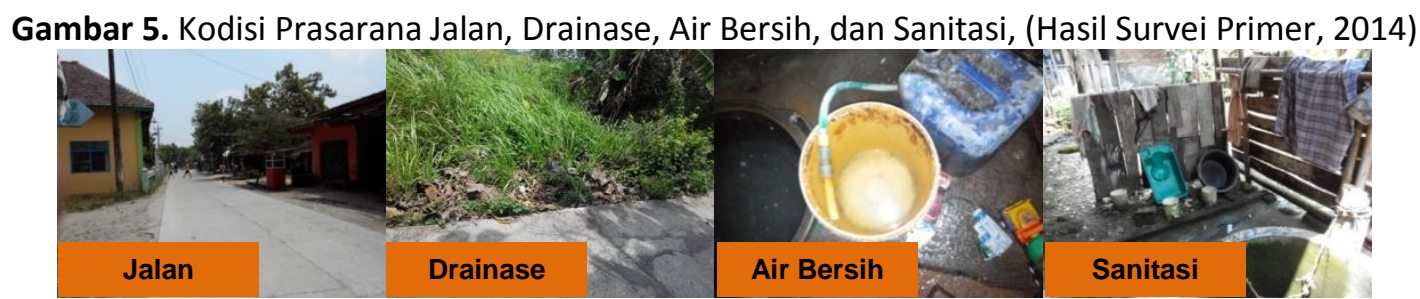

\subsection{Analisis Permukiman Kumuh Berdasarkan Status Tanah}

Status tanah atau hak atas tanah adalah hak penguasaan atas tanah untuk dapat memberikan kewenangan kepada pemegang haknya, agar dapat memakai suatu bidang tanah tertentu yang dihaki dalam memenuhi kebutuhan pribadi atau usahanya (Undang-Undang Nomor 5 Tahun 1960). Sebanyak 67\% rumah kawasan permukiman kumuh di Kecamatan Mranggen belum bersertifikat, sebanyak 33 \% rumah bersertifikat hak milik dan tidak ada rumah yang bersertifikat hak guna bangunan. Rumah yang belum bersertifikat merupakan rumah yang memang tidak memiliki sertifikat dan rumah yang memiliki sertifikat lama bekas rumah orangtua/ orang lain namun sudah tidak berlaku. Alasan penduduk yang rumahnya belum bersertifikat adalah besarnya biaya untuk mengurus sertifikat rumah. Kawasan permukiman kumuh yang identik dengan pendapatan penduduknya yang rendah, tidak mampu membayar pengurusan sertifikat rumah. Disisi lain, peran pemerintah daerah setempat dalam menyediakan pelayanan publik untuk pengurusan sertifikat rumah kurang optimal.

\subsection{Analisis Permukiman Kumuh Berdasarkan Kondisi Kependudukan}

Jumlah penduduk Kecamatan Mranggen tahun 2011 adalah sebanyak 161.680 jiwa yang terdiri atas 80.238 laki-laki dan 81.442 perempuan. Sementara, jumlah penduduk Kecamatan Mranggen tahun 2012 adalah sebanyak 163.773 jiwa terdiri atas 81.156 laki-laki dan 82.617 perempuan. Tingkat pertumbuhan penduduk Kecamatan Mranggen sebesar 1,3\%. Tingkat pertumbuhan penduduk ini cukup rendah karena angka kelahiran dan migrasi masuk besar tetapi angka migrasi keluar juga besar. Kondisi ini terjadi secara alamiah karena pada dasarnya manusia menginginkan kehidupan yang lebih baik. Faktor keahlian juga dapat mempengaruhi kondisi tersebut dimana penduduk yang memiliki keahlian lebih bisa bertahan karena memperoleh kesempatan kerja yang lebih luas. Kepadatan penduduk di Kecamatan Mranggen sebesar 22,38 jiwa/Ha. Kepadatan penduduk ini cukup rendah karena jumlah penduduk yang ada tidak sebanding dengan luas wilayah. 


\subsection{Analisis Permukiman Kumuh Berdasarkan Kondisi Sosial Ekonomi}

Penduduk kawasan permukiman kumuh di Kecamatan Mranggen ada yang bekerja di sektor kekotaan seperti buruh industri, ada pula yang bekerja di sektor kedesaan seperti petani. Sebanyak 99\% penduduk memiliki pendapatan Rp 1.000.000,00 - Rp 1.500.000,00 per bulan dengan jumlah pengeluarannya Rp $1.500 .000,00$ - Rp $1.200 .000,00$ per bulan dan sisanya sebanyak $1 \%$ penduduk memiliki pendapatan Rp 1.500.000,00 - RP 2.000.000,00 per bulan dengan jumlah pengeluaran > RP 2.000.000,00 per bulan. Kondisi ini menunjukkan bahwa tingkat pendapatan penduduk kawasan permukiman kumuh rendah. Dengan kata lain, pendapatan mereka habis digunakan untuk membiaya kebutuhan hidup saja. Sebagian besar penduduk kawasan permukiman kumuh di Kecamatan Mranggen merupakan penduduk pendatang. penduduk yang tinggal $<5$ tahun merupakan penduduk pendatang yang memilih Kecamatan Mranggen sebagai tempat tinggal karena dekat dengan tempat kerja. Sementara penduduk yang tinggal $>5$ tahun merupakan penduduk asli yang sudah tinggal sejak lahir yang memiliki ciri kedesaan. Untuk lebih jelasnya, tingkat kekumuhan kawasan permukiman kumuh berdasarkan kondisi bangunan, aksesbilitas, prasarana, status tanah, kondisi kependudukan, kondisi sosial ekonomi dapat dilihat pada gambar 6, 7, dan 8.

Gambar 6. Peta Tingkat Kekumuhan Kawasan Permukiman Kumuh Berdasarkan Kondisi Bangunan (Kiri), dan Aksesbilitas (Kanan) (Hasil Survei Primer, 2014)
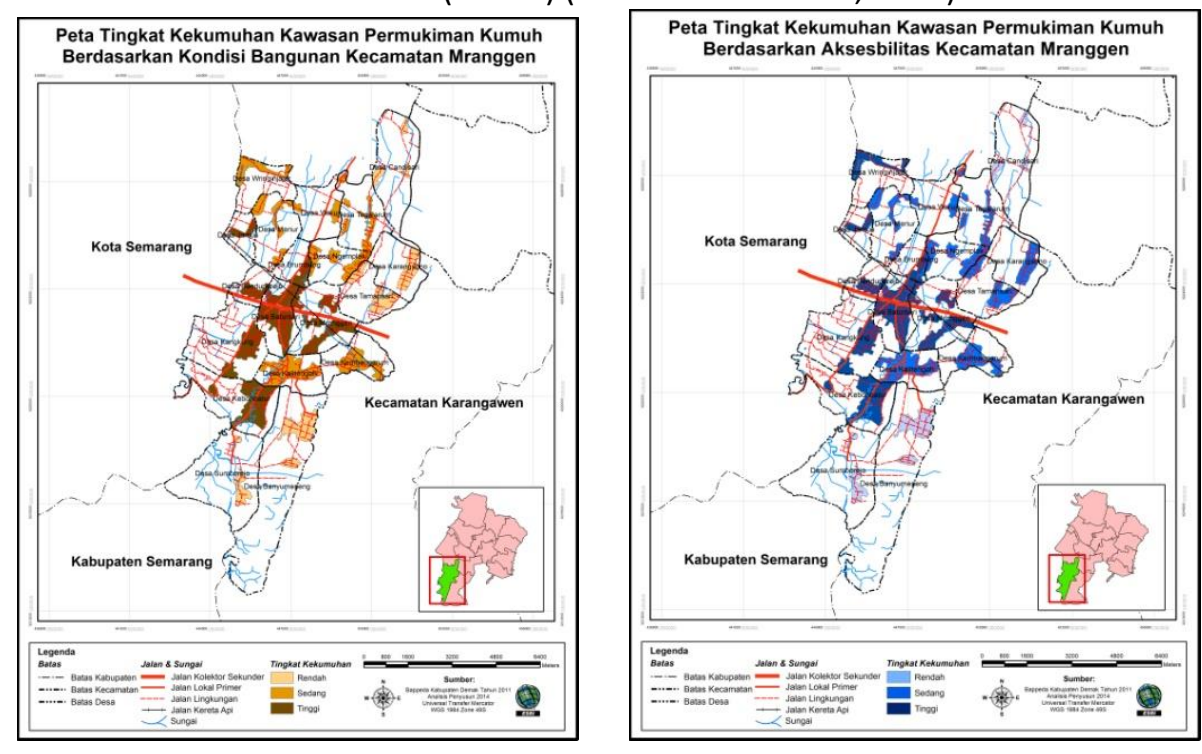

Gambar 7. Peta Tingkat Kekumuhan Kawasan Permukiman Kumuh Berdasarkan Prasarana (Kiri), dan Status Tanah (Kanan), (Hasil Survei Primer, 2014)
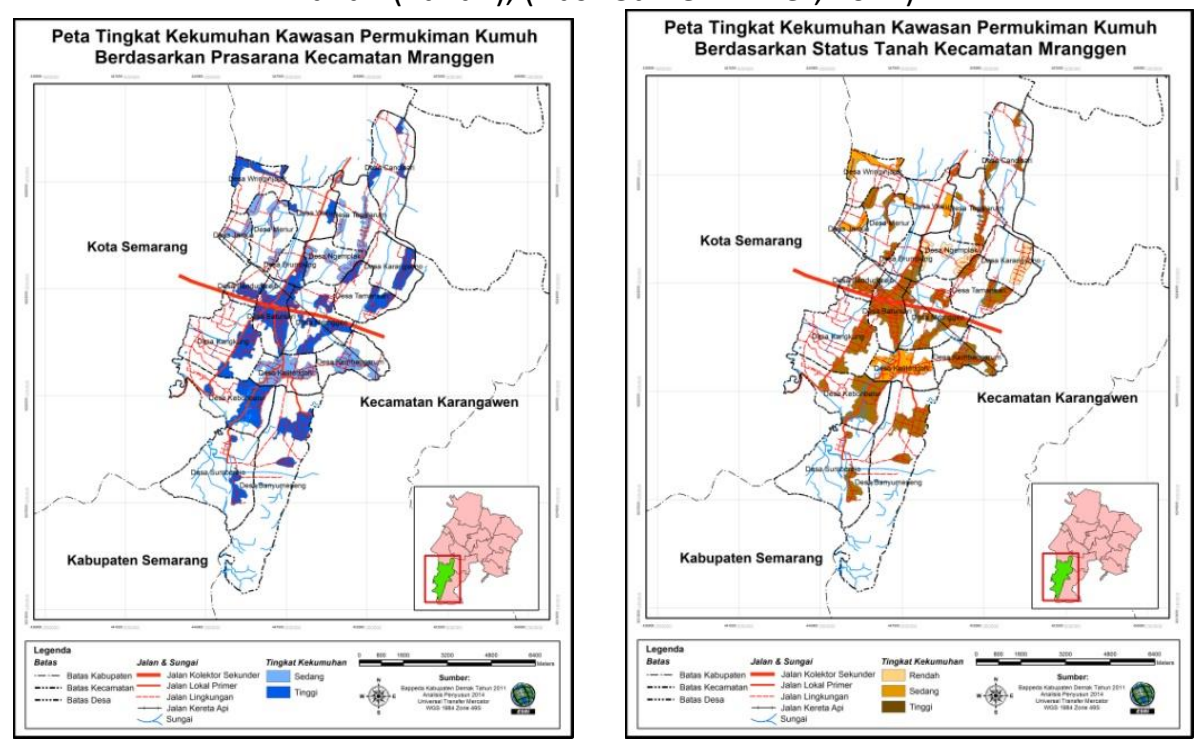
Gambar 8. Peta Tingkat Kekumuhan Kawasan Permukiman Kumuh Berdasarkan Kondisi Kependudukan (Kiri), dan Kondisi Sosial Ekonomi (Kanan), (Hasil Survei Primer, 2014)
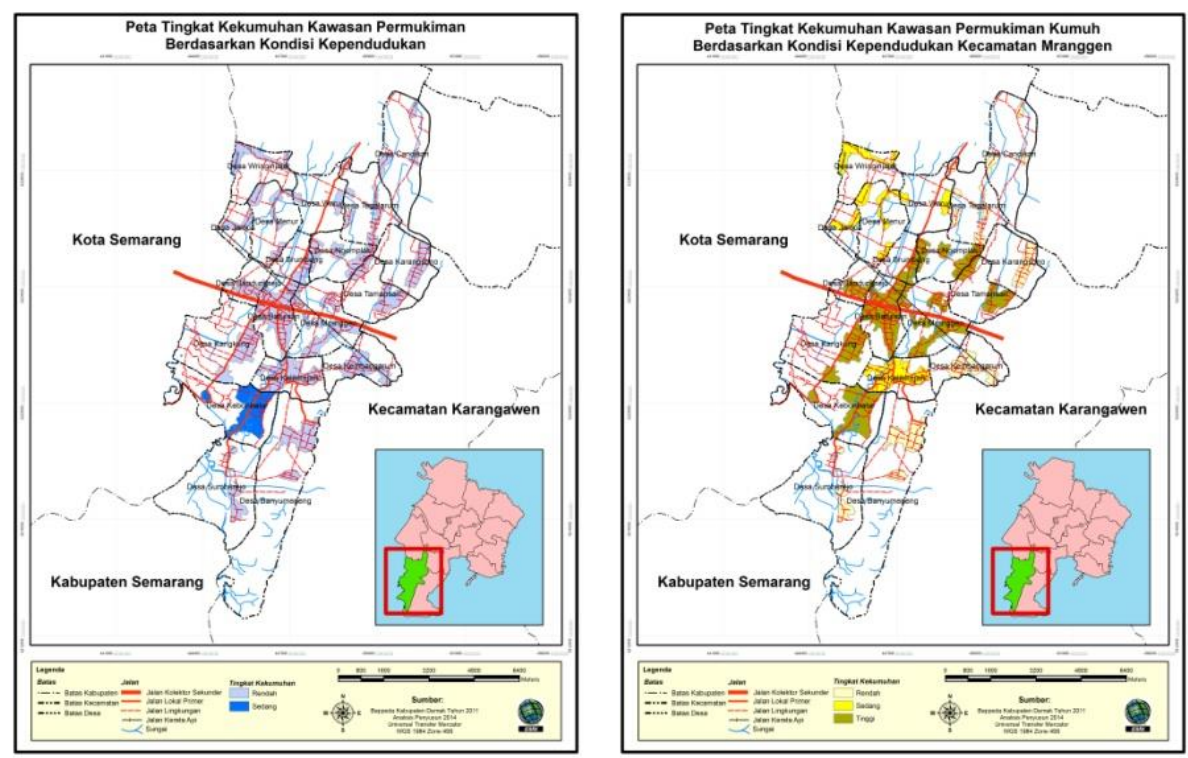

\subsection{Analisis Karakteristik Kawasan Permukiman Kumuh di Kecamatan Mranggen Sebagai Daerah Penyangga Kota Semarang}

Berdasarkan hasil analisis, karakteristik kawasan permukiman kumuh di Kecamatan Mranggen sebagai daerah penyangga Kota Semarang adalah sebagai berikut;

a. Kawasan permukiman kumuh di Kecamatan Mranggen memiliki luas 1652,94 Ha atau 54\% dari luas total permukiman.

b. Kondisi bangunan kawasan permukiman kumuh di Kecamatan Mranggen buruk. $43 \%$ jenis bangunan rumah merupakan bangunan semi permanen, dan $57 \%$ jenis bangunan rumah merupakan bangunan non permanen. Jarak antar bangunan rumah bervariasi yakni $<1,5$ meter, $1,5-3,0$ meter, dan $>3,0$ meter.

c. Tingkat aksesbilitas kawasan permukiman kumuh di Kecamatan Mranggen tinggi. Penduduk dapat mengakses tempat kerja dengan mudah, karena sebagian besar penduduk bekerja di Kota Semarang. Sehingga kawasan permukiman kumuh memiliki lokasi strategis karena dekat dengan Kota Semarang.

d. Kondisi jalan baik karena tingkat mobilitas penduduk tinggi. Namun kondisi drainase, air bersih, dan sanitasi buruk. Kondisi drainase terkesan kurang terpelihara karena sebagian besar saluran drainase kering dan dipenuhi dengan sampah. Kondisi air bersih keruh karena kurangnya kontrol pemerintah terhadap kualitas air bersih. Sebagian besar kawasan permukiman kumuh tidak memiliki jamban atau memiliki tapi dalam kondisi buruk. Penduduk yang tidak memiliki jamban biasanya memanfaatkan sungai atau saluran untuk buang air besar.

e. Status tanah kawasan permukiman kumuh tidak jelas. Sebanyak $67 \%$ rumah belum bersertifikat, sebanyak 33 \% rumah bersertifikat hak milik dan tidak ada rumah yang bersertifikat hak guna bangunan.

f. Tingkat pertumbuhan penduduk rendah yakni $<1,7 \%$ karena angka kelahiran dan migrasi masuk besar tetapi angka migrasi keluar juga besar. Kepadatan penduduk juga rendah yakni $<400$ jiwa/Ha karena jumlah penduduk tidak sebanding dengan luas wilayah yang ada.

g. Kondisi sosial ekonomi penduduk kawasan permukiman kumuh rendah. Tingkat pendapatan rendah yakni sebanyak $99 \%$ penduduk kawasan permukiman kumuh memiliki pendapatan Rp 1.000.000,00 - Rp 1.500.000,00 per bulan dengan jumlah pengeluarannya $R p 1.500 .000,00-R p$ 1.200.000,00 per bulan sehingga pendapatan mereka habis digunakan untuk membiaya kebutuhan hidup saja. Banyak penduduk pendatang yang memilih Kecamatan Mranggen sebagai tempat tinggal karena dekat dengan tempat kerja. 
h. Tingkat kekumuhan kawasan permukiman kumuh di Kecamatan Mranggen terdiri dari tingkat kekumuhan rendah, sedang, dan tinggi. Tingkat kekumuhan rendah berada di Desa Ngemplak. Tingkat kekumuhan sedang berada di Desa Banyumeneng, Desa Sumberejo, Desa Kembangarum, Desa Brumbung, Desa Ngemplak, Desa Karangsono, Desa Tamansari, Desa Menur, Desa Jamus, Desa Wringinjajar, Desa Waru, Desa Tegalarum, dan Desa Candisari. Sementara tingkat kekumuhan tinggi berada di Desa Kebonbatur, Desa Batursari, Desa Kangkung, Desa Mranggen, dan Desa Bandungrejo. Untuk lebih jelasnya, karakteristik tingkat kekumuhan kawasan permukiman kumuh dapat dilihat pada tabel $\mathbf{2}$ berikut.

Tabel 2. Karakteristik Tingkat Kekumuhan Kawasan Permukiman Kumuh Kec. Mranggen (Hasil Analisis, 2014)

\begin{tabular}{|c|c|c|c|c|c|c|}
\hline \multirow[b]{2}{*}{ Lokasi Desa } & \multicolumn{6}{|c|}{ Karakteristik Kawasan Permukiman Kumuh } \\
\hline & $\begin{array}{c}\text { Kondisi } \\
\text { Bangunan }\end{array}$ & Aksesbilitas & Prasarana & Status Tanah & $\begin{array}{c}\text { Kondisi } \\
\text { Kependudukan }\end{array}$ & $\begin{array}{c}\text { Kondisi Sosial } \\
\text { Ekonomi }\end{array}$ \\
\hline Kalitengah & $\begin{array}{l}\text { Lebih dari } 50 \% \\
\text { bangunan } \\
\text { tempat tinggal } \\
\text { merupakan } \\
\text { bangunan semi } \\
\text { permanen } \\
\text { dengan jarak } \\
\text { antar bangunan } \\
\text { 1,5-3,0 meter. }\end{array}$ & $\begin{array}{l}\text { Lebih dari } 50 \% \\
\text { penduduk } \\
\text { memiliki jarak } \\
\text { ke tempat kerja } \\
\text { antara } 1-10 \mathrm{~km} \\
\text { dan berada } \\
\text { pada lokasi } \\
\text { yang cukup } \\
\text { strategis. }\end{array}$ & $\begin{array}{l}\text { Lebih dari } 50 \% \text { kondisi } \\
\text { jalan, drainase, dan air } \\
\text { bersih sedang dan lebih } \\
\text { dari } 50 \% \text { kondisi sanitasi } \\
\text { buruk. }\end{array}$ & $\begin{array}{l}\text { Jumlah rumah } \\
\text { yang belum } \\
\text { bersetifikat } \\
\text { dan } \\
\text { berserk/tifikat } \\
\text { hakmilik } \\
\text { sama. }\end{array}$ & $\begin{array}{l}\text { Tingkat } \\
\text { pertumbuhan } \\
\text { penduduk dan } \\
\text { kepadatan } \\
\text { penduduk yang } \\
\text { rendah yakni } \\
\text { berturut-turut < } \\
1,7 \% \text { dan < } 400 \\
\text { jiwa/Ha. }\end{array}$ & $\begin{array}{l}\text { Lebih dari } 50 \% \\
\text { penduduk } \\
\text { memiliki } \\
\text { pendapatan Rp } \\
1.000 .000,00- \\
\text { Rp } 2.000 .000,00 \\
\text { dan lebih dari } \\
50 \% \text { penduduk } \\
\text { tinggal antara } 1 \text { - } \\
5 \text { tahun. }\end{array}$ \\
\hline $\begin{array}{l}\text { Banyumeneng, } \\
\text { Sumberejo, } \\
\text { Kembangarum, } \\
\text { Brumbung, } \\
\text { Ngemplak, } \\
\text { Karangsono, } \\
\text { Tamansari, } \\
\text { Menur, Jamus, } \\
\text { Wringinjajar, } \\
\text { Waru, } \\
\text { Tegalarum, } \\
\text { dan Candisari }\end{array}$ & $\begin{array}{l}\text { Lebih dari } 50 \% \\
\text { bangunan } \\
\text { tempat tinggal } \\
\text { merupakan } \\
\text { bangunan semi } \\
\text { permanen } \\
\text { dengan jarak } \\
\text { antar bangunan > } \\
3,0 \text { meter. }\end{array}$ & $\begin{array}{l}\text { Lebih dari } 50 \% \\
\text { penduduk } \\
\text { memiliki jarak } \\
\text { ke tempat kerja } \\
\text { antara } 1-10 \mathrm{~km} \\
\text { dan berada } \\
\text { pada lokasi } \\
\text { yang cukup } \\
\text { strategis. }\end{array}$ & $\begin{array}{l}\text { (1) Lebih dari } 50 \% \\
\text { kondisi jalan, drainase, } \\
\text { air bersih, dan sanitasi } \\
\text { buruk, (2) lebih dari } 50 \% \\
\text { kondisi drainase, air } \\
\text { bersih, dan sanitasi } \\
\text { buruk, dan lebih dari } \\
50 \% \text { kondisi jalan baik, } \\
\text { (3) lebih dari 50\% } \\
\text { kondisi drainase, air } \\
\text { bersih, dan sanitasi } \\
\text { buruk, dan lebih dari } \\
50 \% \text { kondisi jalan } \\
\text { sedang, dan (4) lebih } \\
\text { dari } 50 \% \text { kondisi jalan } \\
\text { dan air bersih sedang, } \\
\text { dan lebih dari } 50 \% \\
\text { kondisi drainse dan } \\
\text { sanitasi buruk. }\end{array}$ & $\begin{array}{l}\text { Lebih dari } \\
50 \% \text { rumah } \\
\text { belum } \\
\text { bersertifikat. }\end{array}$ & $\begin{array}{l}\text { Tingkat } \\
\text { pertumbuhan } \\
\text { penduduk dan } \\
\text { kepadatan } \\
\text { penduduk yang } \\
\text { rendah yakni } \\
\text { berturut-turut < } \\
1,7 \% \text { dan }<400 \\
\text { jiwa/Ha. }\end{array}$ & $\begin{array}{l}\text { Lebih dari } 50 \% \\
\text { penduduk } \\
\text { memiliki } \\
\text { pendapatan Rp } \\
1.000 .000,00- \\
\text { Rp } 2.000 .000,00 \\
\text { dan lebih dari } \\
50 \% \text { penduduk } \\
\text { tinggal<1 } \\
\text { tahun. }\end{array}$ \\
\hline $\begin{array}{l}\text { Kebonbatur, } \\
\text { Batursari, } \\
\text { Kangkung, } \\
\text { Mranggen, dan } \\
\text { Bandungrejo }\end{array}$ & $\begin{array}{l}\text { Lebih dari } 50 \% \\
\text { bangunan } \\
\text { tempat tinggal } \\
\text { merupakan } \\
\text { bangunan non } \\
\text { permanen } \\
\text { dengan jarak } \\
\text { antar bangunan< } \\
1,5 \text { meter. }\end{array}$ & 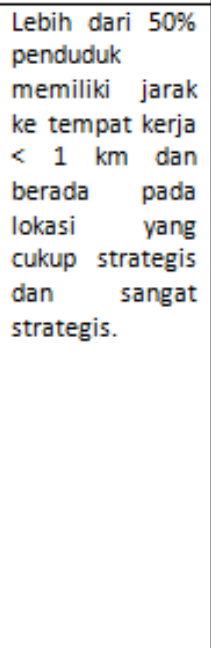 & $\begin{array}{l}\text { (1) Lebih dari } 50 \% \\
\text { kondisi jalan, drainase, } \\
\text { air bersih, dan sanitasi } \\
\text { buruk, (2) lebih dari } 50 \% \\
\text { kondisi drainase, air } \\
\text { bersih, dan sanitasi } \\
\text { buruk, dan lebih dari } \\
50 \% \text { kondisi jalan baik, } \\
\text { (3) lebih dari 50\% } \\
\text { kondisi drainase, air } \\
\text { bersih, dan sanitasi } \\
\text { buruk, dan lebih dari } \\
50 \% \text { kondisi jalan } \\
\text { sedang, dan (4) lebih } \\
\text { dari } 50 \% \text { kondisi jalan } \\
\text { dan air bersih sedang, } \\
\text { dan lebih dari } 50 \% \\
\text { kondisi drainse dan } \\
\text { sanitasi buruk }\end{array}$ & $\begin{array}{l}\text { Lebih dari } \\
50 \% \text { rumah } \\
\text { belum } \\
\text { bersertifikat. }\end{array}$ & $\begin{array}{l}\text { Tingkat } \\
\text { pertumbuhan } \\
\text { penduduk dan } \\
\text { kepadatan } \\
\text { penduduk yang } \\
\text { rendah yakni } \\
\text { berturut-turut < } \\
1,7 \% \text { dan < } 400 \\
\text { jiwa/Ha. }\end{array}$ & $\begin{array}{l}\text { Lebih dari } 50 \% \\
\text { penduduk } \\
\text { memiliki } \\
\text { pendapatan } \mathrm{Rp} \\
1.000 .000,00- \\
\text { Rp } 2.000 .000,00 \\
\text { dan lebih dari } \\
50 \% \text { penduduk } \\
\text { tinggal<1 } \\
\text { tahun. }\end{array}$ \\
\hline
\end{tabular}

Untuk lebih jelasnya, tingkat kekumuhan kawasan permukiman kumuh di Kecamatan Mrangen sebagai daerah penyangga Kota Semarang dapat secara spasial dapat dilihat pada gambar 8 berikut. 
Gambar 8. Peta Tingkat Kekumuhan Kawasan Permukiman Kumuh Kecamatan Mranggen (Hasil Survei Primer, 2014)

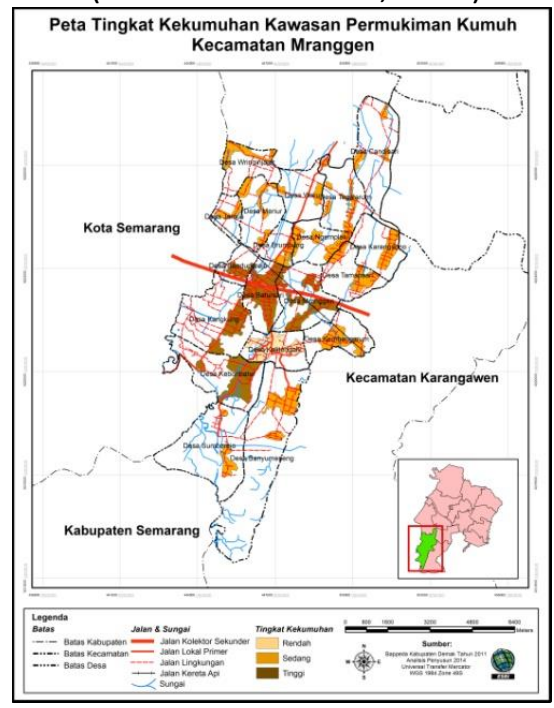

\section{KESIMPULAN}

Berdasarkan hasil penelitian, maka dapat disimpulkan bahwa tingkat kekumuhan kawasan permukiman kumuh di Kecamatan Mranggen terdiri dari tingkat kekumuhan rendah, sedang, dan tinggi. Tingkat kekumuhan rendah berada di Desa Ngemplak. Tingkat kekumuhan sedang berada di Desa Banyumeneng, Desa Sumberejo, Desa Kembangarum, Desa Brumbung, Desa Ngemplak, Desa Karangsono, Desa Tamansari, Desa Menur, Desa Jamus, Desa Wringinjajar, Desa Waru, Desa Tegalarum, dan Desa Candisari. Sementara tingkat kekumuhan tinggi berada di Desa Kebonbatur, Desa Batursari, Desa Kangkung, Desa Mranggen, dan Desa Bandungrejo. Tingkat kekumuhan kawasan permukiman tersebut dilihat dari kondisi bangunan, aksesbilitas, prasarana, status tanah, kondisi kependudukan, dan kondisi sosial ekonomi.

Berdasarkan hasil penelitian, maka dapat direkomendasikan upaya penanganan kawasan permukiman kumuh di Kecamatan Mranggen sebagai berikut:

a. Untuk Desa Kalitengah, dapat ditangani dengan menggunakan pendekatan Community Based Development atau Guided Land Development dengan prioritas perbaikan pada:

1. Memperbaiki kualitas bangunan dari semi permanen menjadi permanen dengan memberikan insentif dana untuk perbaikan rumah.

2. Menyediakan sarana transportasi yang memadai untuk penduduk kawasan kumuh.

3. Memperbaiki kondisi jalan lokal sekunder dan jalan lingkungan.

4. Memperbaiki saluran perpipaan air bersih dan peningkatan kualitas air bersih melalui pengecekan berkala.

5. Memperbaiki saluran drainase dari sedimentasi tanah dan tumpukan sampah.

6. Membangun MCK komunal bagi penduduk kawasan permukiman kumuh yang tidak memiliki MCK.

7. Memberikan peringatan dan punishment bagi rumah penduduk yang belum bersertifikat. Untuk rumah yang bersertifikat namun sudah tidak berlaku, pemerintah sebaiknya memfasilitasi pengurusan sertifikat rumah.

8. Memberikan modal pinjaman usaha melalui koperasi agar penduduk kawasan kumuh dapat memiliki pendapatan di sektor lain untuk meningkatkan taraf hidup .

b. Untuk Desa Banyumeneng, Desa Sumberejo, Desa Kembangarum, Desa Brumbung, Desa Ngemplak, Desa Karangsono, Desa Tamansari, Desa Menur, Desa Jamus, Desa Wringinjajar, Desa Waru, Desa Tegalarum, dan Desa Candisari, dapat ditangani dengan menggunakan pendekatan Community Based Development atau Guided Land Development dengan prioritas perbaikan pada:

1. Memperbaiki kualitas bangunan dari semi permanen menjadi permanen dengan memberikan insentif dana untuk perbaikan rumah. 
2. Melakukan perbaikan jalan, drainase, air bersih, dan sanitasi.

3. Menyediakan sarana transportasi yang memadai untuk penduduk kawasan kumuh.

4. Memperbaiki dan membangun jalan lokal sekunder dan jalan lingkungan.

5. Memperbaiki dan membangun saluran perpipaan air bersih dan meningkatkan kualitas air bersih melalui pengecekan berkala.

6. Memperbaiki dan membangun saluran drainase.

7. Membangun MCK komunal bagi penduduk kawasan permukiman kumuh yang tidak memiliki MCK.

8. Memberikan peringatan dan punishment bagi rumah penduduk yang belum bersertifikat.

9. Memberikan modal pinjaman usaha melalui koperasi agar penduduk kawasan kumuh dapat memiliki pendapatan di sektor lain untuk meningkatkan taraf hidup.

c. Untuk Desa Kebonbatur, Desa Batursari, Desa Kangkung, Desa Mranggen, dan Desa Bandungrejo, dapat ditangani dengan menggunakan pendekatan Poverty Development dengan prioritas perbaikan pada:

1. Membuat program rumah murah dengan kualitas bangunan non permanen.

2. Menyediakan sarana transportasi yang memadai untuk penduduk kawasan kumuh.

3. Memperbaiki dan membangun jalan kolektor sekunder, jalan lokal sekunder dan jalan lingkungan.

4. Memperbaiki dan membangun saluran perpipaan air bersih dan meningkatkan kualitas air bersih melalui pengecekan berkala.

5. Memperbaiki dan membangun saluran drainase.

6. Membangun MCK komunal bagi penduduk kawasan permukiman kumuh yang tidak memiliki MCK.

7. Memberikan peringatan dan punishment bagi rumah penduduk yang belum bersertifikat.

8. Memberikan modal pinjaman usaha melalui koperasi agar penduduk kawasan kumuh dapat memiliki pendapatan di sektor lain untuk meningkatkan taraf hidup.

\section{DAFTAR PUSTAKA}

Bintarto. 1983. Interaksi Desa Kota dan Permasalahannya. Jakarta : Ghalia Indonesia.

Direktorat Pengembangan Permukiman Direktorat Jenderal Cipta Karya - Departemen Pekerjaan Umum.2006. Konsep Pedoman Identifikasi Kawasan Permukiman Kumuh Penyangga Kota Metropolitan.

Giok Ling Ooi and Kai Hong Phua. 2007. Urbanization and Slum Formation. Journal of Urban Health: Bulletin of the New York Academy of Medicine, Vol. 84, No. 1.

Hari Srinivas, 2003, Slum, Squatter Areas and Informal Settlement, $9^{\text {th }}$ International Conference On Sri Lanka Studies, Matara, Sri Lanka, Arawinda Nawagamuwa and Nils Viking.

Khomarudin. 1997. Menelusuri Pembangunan Perumahan dan Permukiman. Jakarta : Yayasan Real Estate Indonesia, PT. Rakasindo.

Malaque, Isidoro and Yokohari Makoto. 2007. Urbanization process and the changing agricultural landscape pattern in the urban fringe of Metro Manila, Philiphines. http://www.sagepublications.com.

Mulyadi. 2007. Penginderaan Jauh dan Interpretasi Citra. Jakarta : LAPAN.

Pigawati, Bitta. 2014. Seminar Nasional Kota Hijau pesisir Tropis: Kajian Permukiman Pesisir Kota Semarang Berkelanjutan; Karakteristik, Tata ruang dan Kebijakan. Tidak diterbitkan.

Tarigan, Robinson. 2005. Perencanaan Pembangunan Wilayah. Jakarta : PT. Bumi Aksara.

UN-HABITAT. 2003. The Challenge of Slum : Global Report on Human Settlements. United Nations Huma Settlemnets Programme.

Undang-Undang Nomor 5 Tahun 1960 tentang Undang-Undang Pokok Agraria.

Yunus, Hadi Sabari. 2008. Dinamika Wilayah Peri Urban Determinan Masa Depan kota. Yogyakarta : Pustaka Pelajar.

Yudohusodo, S. 1991. Tumbuhnya Pemukim-Pemukim Liar di Kawasan Perkotaan. Jakarta : Yayasan Padamu Negeri. 